\title{
SPATIAL AND TEMPORAL VARIATION IN THE DISTRIBUTION AND ABUNDANCE OF PELAGIC FISH EGGS AND LARVAE OFF GIRESUN, SOUTH-EASTERN BLACK SEA, TURKEY
}

\author{
Ahmet ŞAHIN** and Ertuğ DÜZGÜNEŞ \\ Faculty of Marine Sciences, Karadeniz Technical University, Trabzon, Turkey
}

Şahin A., Düzgüneş E. 2019. Spatial and temporal variation in the distribution and abundance of pelagic fish eggs and larvae off Giresun, south-eastern Black Sea, Turkey. Acta Ichthyol. Piscat. 49 (2): 159-169.

\begin{abstract}
Background. Giresun Bay is an important spawning ground of many migratory fish species and hence it has been a major fishing area of pelagic fishes in the Turkish territorial waters of the Black Sea. However, this area has not been evaluated thoroughly for the abundance and distribution of pelagic fish eggs and larvae, which are prerequisite for understanding the dynamics of fluctuating fish populations. The presently-reported study aimed to fill this gap in the existing knowledge of spatial and temporal variation in the distribution and abundance of ichthyoplankton in the south-eastern Black Sea.

Material and methods. Bimonthly surveys were carried out from January through November 2009 at inshore and offshore sites $\left(>38^{\circ} \mathrm{E},>40^{\circ} \mathrm{N}\right)$. The samples were collected by horizontal tows with Manta nets. The mouth of the net was equipped with flowmeters to measure the amount of water passing through the net during each tow. Results. The horizontal tows returned a total of 13556 eggs and 1304 larvae representing 26 species (from 22 families): Engraulis encrasicolus, Sprattus sprattus, Merlangius merlangus, Gaidropsarus mediterraneus, Atherina boyeri, Scorpaena porcus, Chelidonichthys lucerna, Dicentrarchus labrax, Trachurus mediterraneus, Diplodus annularis, Sciaena umbra, Mullus barbatus, Gymnammodytes cicerelus, Ctenolabrus rupestris, Symphodus ocellatus, Trachinus draco, Uranoscopus scaber, Parablennius sanguinolentus, Parablennius tentacularis, Blennius sp., Ophidion rochei, Callionymus pusillus, Gobius sp., Arnoglossus kessleri, Buglossidium luteum, Pegusa lascaris. Overall, the dominant species were E. encrasicolus with $89.8 \%$ of all collected eggs, followed by G. mediterraneus (7.0\%). Similarly, $47.4 \%$ of the total larvae were represented by E. encrasicolus, followed by $P$. sanguinolentus (22.8\%) and S. sprattus (13.2\%). The colder months (January, March, and November) presented a total of four species: S. sprattus, B. luteum, Gymnammodytes cicerelus, and Gaidropsarus mediterraneus. The warmer months had a greater variety of different species than colder months. Of these, E. encrasicolus was the most dominant species, providing the maximum abundance of fish eggs and larvae in September. The abundance of E. encrasicolus eggs and larvae decreased from offshore toward inshore sites highlighting the preference of this species to deeper waters for spawning as well as for nursery purposes in Giresun Bay.

Conclusion. The results of this study suggest that the length of the closed fishing season in the Black Sea should be reconsidered. We suggest that it should be extended to include also the last week of September in order to provide more time for pelagic fish (e.g., E. encrasicolus) to complete their spawning period. This could result in a healthier and more sustainable stock of E. encrasicolus in the Black Sea.
\end{abstract}

Keywords: anchovy, abundance, distribution, ichthyoplankton, spawning season

\section{INTRODUCTION}

The Black Sea is home to many migratory fish species, either pelagic such as European anchovy, Engraulis encrasicolus ${ }^{* *}$, European sprat, Sprattus sprattus, and Mediterranean horse mackerel, Trachurus mediterraneus or demersal such as turbot, Scophthalmus maximus, whiting, Merlangius merlangus, picked dogfish, Squalus acanthias, red mullet, Mullus barbatus, and striped mullet, Mullus surmuletus for reproduction and feeding (Popescu 2010). The pelagic fishes are the most abundant, accounting for more than $60 \%$ (in 1994) of the total worldwide marine fish landings (Grainger and Garcia 1996). Anchovy alone contributed to over $75 \%$ of the total fish production in 1995 from the Black Sea (Popescu 2010). Furthermore, pelagic fishes also play a vital role in the ocean food web, providing food for piscivorous fishes, marine mammals, and seabirds (Checkley et al. 2017). Also, they are the major source of fishmeal used in aquaculture feed production with 23.8 million $t$ used worldwide in 2006 (Tacon and Metian 2009).

\footnotetext{
" Correspondence: Dr Ahmet Şahin, Karadeniz Teknik Üniversitesi, Sürmene Deniz Bilimleri Fakültesi Çamburnu Kampüsü 61530, Çamburnu/Trabzon, Turkey, phone: +90 462 7522805, fax: +90 462 7522158, e-mail: (AŞ) asahin@ktu.edu.tr, (ED) ertug@ktu.edu.tr.

${ }^{* *}$ Full names of all fish species discussed are provided in the Results.
} 
More than half of the Turkish marine fisheries are from the Black Sea (Duzgunes et al. 2014). The pelagic fish species, mentioned above, yielded $287152 \mathrm{t}(83.05 \%)$ in 2015 and $163969 \mathrm{t}(62.2 \%)$ in 2016 of the total marine fish harvested in Turkey (Anonymous 2016, 2017a). In 2015 and 2016, anchovy was the most harvested fish species $(56.0 \%$ and $38.9 \%$ ) followed by sprat with $22.3 \%$ and $19.0 \%$ of the total landings of marine fishes in Turkey. The population of these two species decreased by 55.6 percentage points in 2016 with respect to the previous year (Anonymous 2016, 2017a).

The survival, successful development, and growth of fish, and their subsequent recruitment to the population, are largely dependent on a wide range of biological (e.g., predator avoidance and food availability) and physical factors (e.g., temperature, salinity, winds, and ocean currents) (see Roussel et al. 2010). Ecological disturbances within the Black Sea were noted during the early 1970s (Satilmis et al. 2003) with the successful invasion of the mollusc veined rapa whelk (Rapana venosa) and during the latter part of the 20th century another species, the ctenophore Mnemiopsis leidyi, invaded the Black Sea and became the dominant zooplanktonic species in terms of the biomass (Vinogradov et al. 1989, Satilmis et al. 2003). Apart from being a food competitor for fish, its direct predation on fish eggs and larvae represent a threat to fish stocks (Hamer et al. 2010). The Black Sea is also subject to discharge of municipal, industrial, and agricultural waste from increased urbanization (Topcuoğlu et al. 2003, Alkan et al. 2015). Influences on water quality, resulting from these human activities, are also likely to affect the composition, distribution, and abundance of ichthyoplankton in the Black Sea (Satilmis et al. 2003), with subsequent effects on fish production.

Extensive ichthyoplankton studies have been carried out in the Turkish Exclusive Economic Zone of the Black Sea dating back to a number of studies done prior to 2015
(Slastenenko 1956, Niermann et al. 1994, Kideys et al. 1999, Şahin and Hacimurtazaoğlu 2013). However, some parts of the Black Sea, such as Giresun Bay, have not been evaluated thoroughly for ichthyoplankton distribution and abundance. Giresun Bay is an important spawning ground of many migratory fish species and hence it has been a major fishing area of pelagic fishes in the Turkish part of the Black Sea. According to the Giresun Provincial Directorate of Environment and Urbanization (Anonymous 2017b), this bay is substantially affected by densely populated coastal communities, discharging their municipal, industrial and agricultural wastes directly to the Black Sea. In this study, the distribution and abundance of the pelagic ichthyoplankton in Giresun Bay and the adjacent waters were thoroughly evaluated at inshore and offshore sites throughout four seasons. The data resulting from this study will provide information about the ichthyoplankton community structure and their spawning period in the studied area.

\section{MATERIALS AND METHODS}

Study area and sampling survey. The sampling surveys were carried out off Giresun, the south-eastern Black Sea, within territorial waters of Turkey. The sampling sites included four stations: St. $1\left(38.368^{\circ} \mathrm{E}, 41.009^{\circ} \mathrm{N}\right.$, depth $>100 \mathrm{~m})$, St. $2\left(38.368^{\circ} \mathrm{E}, 40.967^{\circ} \mathrm{N}\right.$, depth $\left.>100 \mathrm{~m}\right)$, St. $3\left(38.369^{\circ} \mathrm{E}, 40.924^{\circ} \mathrm{N}\right.$, depth $\left.\cong 35 \mathrm{~m}\right)$, and St. 4 $\left(38.380^{\circ} \mathrm{E}, 40.920^{\circ} \mathrm{N}\right.$, depth $\left.\cong 15 \mathrm{~m}\right)$ located within the Giresun harbour (Fig. 1).

A bimonthly sampling of ichthyoplankton was done during daylight hours from January through November 2009 using a $0.25 \mathrm{~m}^{2}$-opening area and $2.3 \mathrm{~m}$ in length Manta net. The mouth of the net was equipped with flowmeters (General Oceanics Model 2030) to measure the amount of water passing through the net during each tow (Smith and Richardson 1977). The water temperature $\left({ }^{\circ} \mathrm{C}\right)$ and the salinity $(\%)$ were also measured

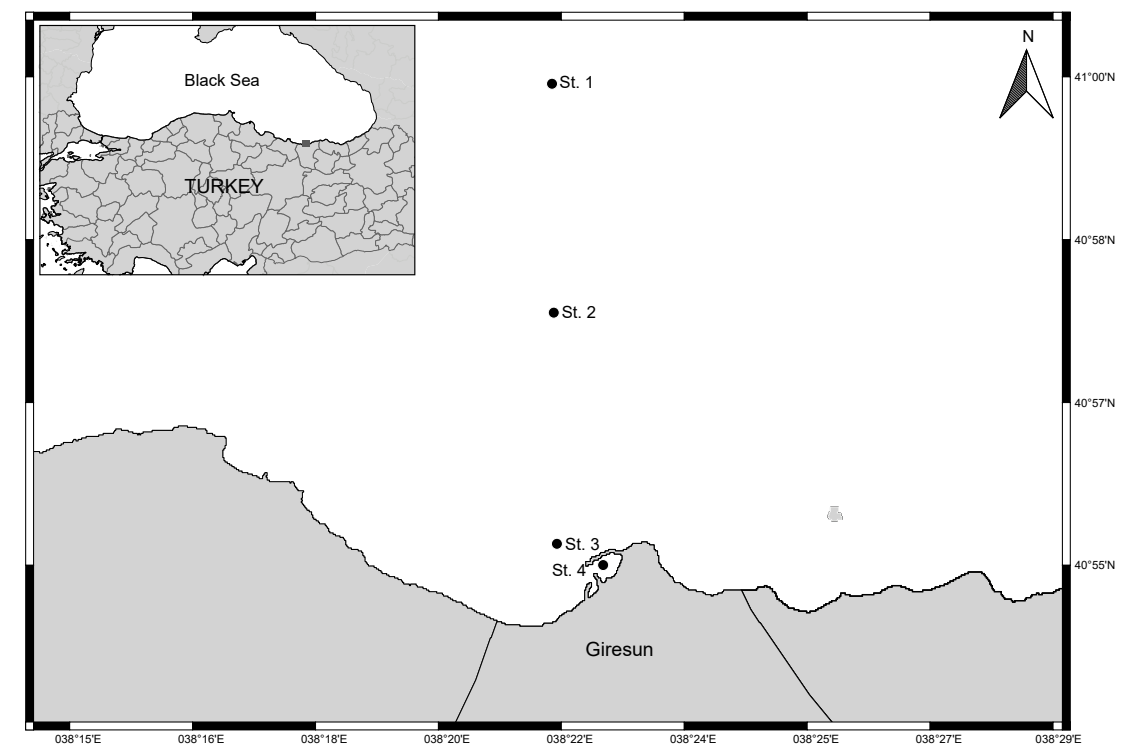

Fig. 1. Map showing the location of the stations (St.1, St. 2, St. 3., St. 4) in Giresun Bay and its offshore areas (southeastern Black Sea, Turkey) surveyed for ichthyoplankton from January through November 2009 
at all stations throughout each survey by General Oceanic CTD Probe (model 316) developed by Idronaut. The R/V KTÜ Yakamoz (10 m LOA) was used to collect samples.

The Manta net was towed horizontally (water surface, $0.5 \mathrm{~m} \mathrm{depth}$ ) at all stations for $10 \mathrm{~min}$ at a vessel speed of 1.7-2.2 knots. Upon retrieval, the net was carefully washed down, and the samples were then removed from the codend and fixed immediately in $4 \%$ formaldehyde solution for subsequent laboratory investigation.

Laboratory work. The fish eggs and larvae were separated from the rest of the plankton. They were identified to the lowest possible taxa based on pigmentation, meristic, and morphometric characteristics (Dehnik 1973, Russell 1976, Ahlstrom and Moser 1980) using Leica MZ6 stereoscopic microscope and were then quantified.

Data analyses. The number of fish eggs and larvae were standardized to a volume of $100 \mathrm{~m}^{-3}$ for the horizontal tow. The statistical significance was tested by a $t$-test and one-way ANOVA. Pearson correlation was carried out on "fish eggs and larvae" and "environmental parameters temperature and salinity" in order to evaluate the association of environmental variables with the abundance of fish eggs and larvae (Lopes et al. 2014). For Pearson correlation, all variables were log-transformed $(\log (x+1))$ before the normalization. A dendrogram was constructed to determine the similarities or dissimilarities among different sampling months and stations. R (v. 3.5.0) and Primer version 6.1 (PRIMER-E Ltd, Luton, UK) software were used for statistical analyses.

\section{RESULTS}

Hydrography. The sea surface temperature (SST) ranged from 8.9 to $25.3^{\circ} \mathrm{C}$ (at $5 \mathrm{~m}$ depth) for the four stations. SST was significantly different among different sampling months (one-way ANOVA, $P<0.001$ ). However, there was no significant difference among different sampling stations for each sampling month (one-way ANOVA, $P$ $>0.05)$. The lowest and highest SST was recorded during March and August, respectively (Fig. 2). Thermal stratification was minimal during May whereas a strong stratification was observed in July and September at stations St. 1 and St. 2.

The sea surface salinity (SSS, salinity at $5 \mathrm{~m}$ ) ranged from $17.0 \%$ o to $18.1 \%$ with a mean $( \pm \mathrm{SE})$ of $17.6 \pm 0.1 \%$ for all sampling stations (Fig. 3). The minimum-maximum salinities for each station were, $17.47 \% 0-18.03 \%$ (St. 1), $17.08 \% 0-18.06 \%$ (St. 2), 17.08\%o-18.02\%o (St. 3), and $16.97 \%-17.99 \%$ (St. 4). The highest values of SSS were recorded during January for all sampling stations, while the lowest SSS was recorded in November for St. 1 and St. 2 and in May for St. 3 and St. 4.

Overall ichthyoplankton composition. Throughout the study, a total of 13556 eggs and 1304 larvae were identified as 26 species (from 22 different families): Engraulis encrasicolus (Linnaeus, 1758); Sprattus sprattus (Linnaeus, 1758); Merlangius merlangus (Linnaeus, 1758); Gaidropsarus mediterraneus (Linnaeus, 1758); Atherina boyeri Risso, 1810; Scorpaena porcus Linnaeus, 1758; Chelidonichthys lucerna (Linnaeus, 1758); Dicentrarchus labrax (Linnaeus, 1758); Trachurus mediterraneus (Steindachner, 1868); Diplodus annularis (Linnaeus, 1758); Sciaena umbra Linnaeus, 1758; Mullus barbatus Linnaeus, 1758; Gymnammodytes cicerelus (Rafinesque, 1810); Ctenolabrus rupestris (Linnaeus, 1758); Symphodus ocellatus (Linnaeus, 1758); Trachinus draco Linnaeus, 1758; Uranoscopus scaber Linnaeus, 1758; Parablennius sanguinolentus (Pallas, 1814); Parablennius tentacularis (Brünnich, 1768); Blennius sp.; Ophidion rochei Müller, 1845; Callionymus pusillus Delaroche, 1809; Gobius sp.; Arnoglossus kessleri

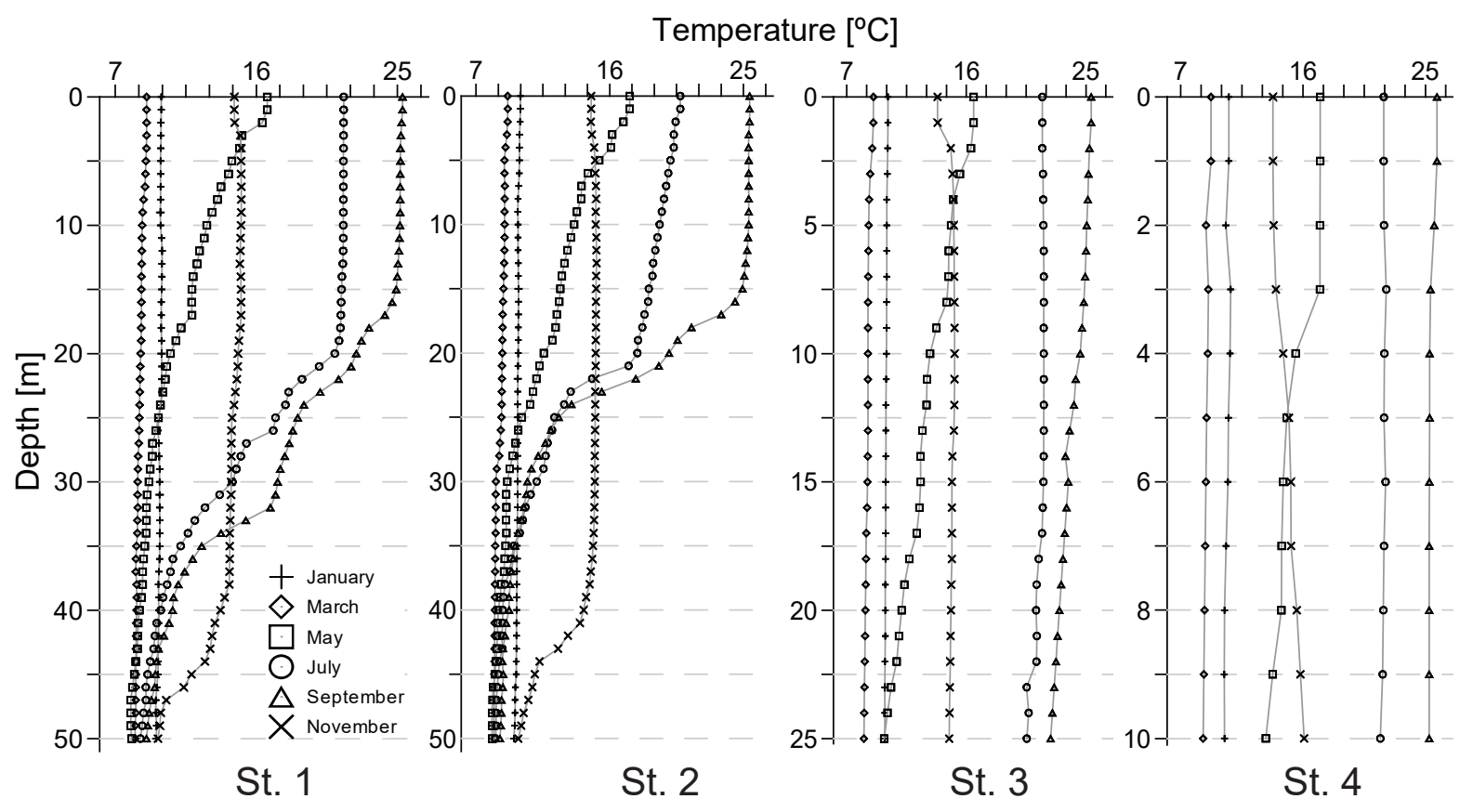

Fig. 2. Depth profiles of temperature $\left({ }^{\circ} \mathrm{C}\right)$ at Giresun Bay and its offshore areas, the south-eastern Black Sea, Turkey 
Schmidt, 1915; Buglossidium luteum (Risso, 1810); Pegusa lascaris (Risso, 1810). Of these, eight species were represented by eggs and larvae, ten species only as larvae, and eight as eggs. Up to $97.7 \%$ of the total relative abundance was composed of eggs from three species: E. encrasicolus $(89.8 \%)$, G. mediterraneus $(7.0 \%)$, and M. barbatus $(1.1 \%)$. Similarly, over $83 \%$ of larvae are represented by E. encrasicolus (47.4\%), Parablennius sanguinolentus (22.8\%), and Sprattus sprattus (13.2\%). A greater variety of ichthyoplankton species were consistently acquired from horizontal tows (Table 1).

Temporal dynamics of ichthyoplankton. During colder months (January, March, and November), the eggs and larvae of $S$. sprattus were found most often in the study area followed by the eggs of $G$. mediterraneus. Both eggs and larvae of $G$. mediterraneus were observed to be at peak density during January.

The eggs of E. encrasicolus were first found in samples obtained during May. The density of E. encrasicolus eggs increased from May to September (Table 2). The distribution of E. encrasicolus eggs was significantly similar ( $t$-test, $P=0.64$ ) between July and September. The larvae of E. encrasicolus were found to appear during July and September. Just like eggs distribution, the abundance of larvae increased from July to September (Table 2). Moreover, a greater variety of different species of larvae were recorded in July and September.

Dendrogram assessment based on Bray-Curtis similarities was used to aggregate the most similar months and stations of ichthyoplankton. For temporal variation, two principal groups were identified, covering January, March, November, and May, July, September for both eggs and larvae showing complete dissimilarity in terms of ichthyoplankton composition (Fig. 4). The egg composition showed the highest similarities between January-March ( $90 \%)$ while November shared $\sim 50 \%$ similarity. July-September showed high similarity ( $\sim 80 \%$ ), but May shared only $20 \%$ similarity with them. For the larvae composition, July-September showed $\sim 70 \%$ similarity, while May shared only $20 \%$ similarity as for the eggs composition, while January-March-November shared $\sim 65 \%$ similarity. The dendrogram results showed greater temporal variation than spatial.

Ichthyoplankton composition by area. Engraulis encrasicolus eggs were encountered at all sampling stations. They were most numerous and prevalent at St. 1, St. 2, and St. 3 and showed the highest density at St. 1. Their density decreased from offshore to inshore stations. Station 4 was dominated by M. barbatus eggs. Furthermore, E. encrasicolus larvae, as the most abundant at St. 1 and St. 2 only, and their highest density was observed at St. 1. Stations St. 3 and St. 4 were dominated by $G$. mediterraneus larvae (Table 3 ). A wide variety of fish larvae were encountered at St. 2 (20 species) and St. 3 (18 species), while St. 1 had the least variety of fish larvae (12 species). Similarly, stations St. 2 and St. 3 had eggs of 6 and 5 different species, respectively.

The dendrogram (Fig. 4) identified that stations St. 1 and St. 2 showed the greatest similarity for eggs composition and shared $\sim 80 \%$ similarity. They were separated from St. 3 but still shared more than $70 \%$ similarities, while St. 4 showed only $55 \%$ similarity with the other stations. In contrast, for larvae composition, stations St. 2, St. 3, and St. 4 shared $\sim 70 \%$ similarity, while St. 1 shared $\sim 55 \%$ similarities with the other station (Fig. 4). Furthermore, SIMPER analysis indicated a comparable trend in similarities for eggs and larvae (Table 4). However,

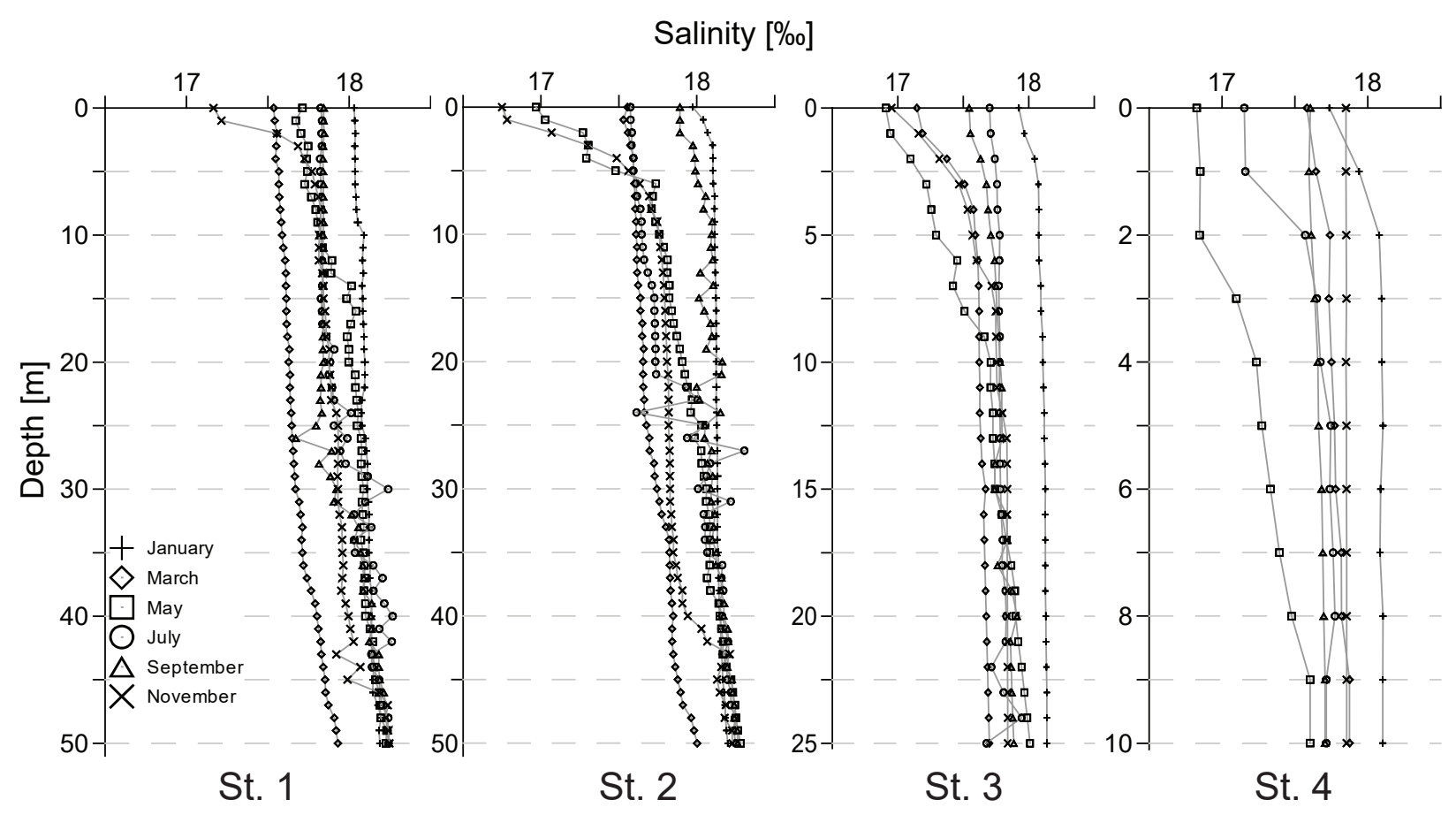

Fig. 3. Depth profiles of water salinity (ppt.) at Giresun Bay and its offshore areas, the south-eastern Black Sea, Turkey 
the mean dissimilarity above $90 \%$ was considered as however, was observed between fish larvae and salinity significant. Egg composition between stations 1-4, 2-4, (except for S. sprattus). Furthermore, both eggs and larvae and 3-4 was significantly different. Larvae composition of E. encrasicolus were positively correlated with the among all stations was not significantly different.

Pearson correlation. The summarized results of the Pearson correlation test are given in Table 5. A strong negative correlation was observed between the salinity and the egg abundance of Engraulis encrasicolus, Trachurus mediterraneus, Uranoscopus scaber, and temperature and hence, their high density was associated with higher temperature.

\section{DISCUSSION}

The surveyed area was largely dominated by eggs

Table 1

The overall total number of fish eggs and larvae collected during bimonthly sampling from January to November 2009 from Giresun Bay and its offshore areas, south-eastern Black Sea, Turkey

\begin{tabular}{|c|c|c|c|c|c|c|c|c|c|}
\hline \multirow[t]{2}{*}{ Taxa } & \multirow[t]{2}{*}{ Species } & \multicolumn{2}{|c|}{ Total number } & \multicolumn{2}{|c|}{$\begin{array}{c}\text { Relative } \\
\text { abundance [\%] }\end{array}$} & \multicolumn{2}{|c|}{$\begin{array}{l}\text { Frequency } \\
{[\%]}\end{array}$} & \multicolumn{2}{|c|}{$\begin{array}{l}\text { Numbers in horizontal tows } \\
\qquad\left[100 \mathrm{~m}^{-3}\right]\end{array}$} \\
\hline & & Egg & Larvae & Egg & Larvae & Egg & Larvae & Egg & Larvae \\
\hline \multicolumn{10}{|l|}{ Clupeiformes } \\
\hline Engraulidae & Engraulis encrasicolus & 12149 & 618 & 89.6 & 47.4 & 50.0 & 33.3 & $1605.7 \pm 682.0$ & $125.1 \pm 58.6$ \\
\hline Clupeidae & Sprattus sprattus & 37 & 172 & 0.3 & 13.2 & 33.3 & 25.0 & $4.4 \pm 1.5$ & $24.5 \pm 17.1$ \\
\hline \multicolumn{10}{|l|}{ Gadiformes } \\
\hline Gadidae & Merlangius merlangus & 5 & - & $<0.1$ & - & 12.5 & - & $2.6 \pm 0.3$ & - \\
\hline Lotidae & Gaidropsarus mediterraneus & 955 & - & 7.0 & - & 33.3 & - & $110.1 \pm 45.8$ & - \\
\hline \multicolumn{10}{|l|}{ Atheriniformes } \\
\hline Atherinidae & Atherina boyeri & - & 8 & - & 0.6 & - & 12.5 & - & $3.3 \pm 1.9$ \\
\hline \multicolumn{10}{|c|}{ Scorpaeniformes } \\
\hline Scorpaenidae & Scorpaena porcus & 54 & - & 0.4 & - & 20.8 & - & $14.6 \pm 5.2$ & - \\
\hline Triglidae & Chelidonichthys lucerna & - & 1 & - & $<0.1$ & - & 4.2 & - & 1.2 \\
\hline \multicolumn{10}{|l|}{ Perciformes } \\
\hline Moronidae & Dicentrarchus labrax & 3 & - & $<0.1$ & - & 12.5 & - & $1.6 \pm 0.2$ & - \\
\hline Carangidae & Trachurus mediterraneus & 114 & - & 0.8 & - & 12.5 & - & $52.7 \pm 14.3$ & - \\
\hline Sparidae & Diplodus annularis & - & 41 & - & 3.1 & - & 20.8 & - & $11.9 \pm 4.5$ \\
\hline Sciaenidae & Sciaena umbra & 3 & 2 & $<0.1$ & 0.2 & 4.2 & 8.3 & 4.2 & $1.3 \pm 0.1$ \\
\hline Mullidae & Mullus barbatus & 154 & 23 & 1.1 & 1.8 & 25.0 & 20.8 & $35.0 \pm 17.2$ & $6.9 \pm 4.3$ \\
\hline Ammodytidae & Gymnammodytes cicerelus & - & 5 & - & 0.4 & - & 8.3 & - & $4.2 \pm 2.5$ \\
\hline \multirow[t]{2}{*}{ Labridae } & Ctenolabrus rupestris & 27 & 2 & 0.2 & 0.2 & 12.5 & 8.3 & $4.4 \pm 2.3$ & $0.5 \pm 0.1$ \\
\hline & Symphodus ocellatus & - & 2 & - & 0.2 & - & 4.2 & - & 2.7 \\
\hline Trachinidae & Trachinus draco & 1 & - & $<0.1$ & - & 4.2 & - & 1.4 & - \\
\hline Uranoscopidae & Uranoscopus scaber & 6 & - & $<0.1$ & - & 16.7 & - & $2.3 \pm 0.7$ & - \\
\hline \multirow[t]{3}{*}{ Blenniidae } & Parablennius sanguinolentus & - & 297 & - & 22.8 & - & 45.8 & - & $38.0 \pm 21.2$ \\
\hline & Parablennius tentacularis & - & 45 & - & 3.5 & - & 16.7 & - & $17.1 \pm 3.9$ \\
\hline & Blennius sp. & - & 46 & - & 3.5 & - & 8.3 & - & $32.2 \pm 22.8$ \\
\hline Ophidiidae & Ophidion rochei & 13 & - & $<0.1$ & - & 16.7 & - & $4.2 \pm 2.2$ & - \\
\hline Callionymidae & Callionymus pusillus & - & 1 & - & $<0.1$ & - & 4.2 & - & 1.5 \\
\hline Gobidae & Gobius sp. & - & 39 & - & 3.0 & - & 20.8 & - & $6.9 \pm 2.6$ \\
\hline \multicolumn{10}{|c|}{ Pleuronectiformes } \\
\hline Bothidae & Arnoglossus kessleri & 31 & 2 & 0.2 & 0.2 & 8.3 & 4.2 & $18.4 \pm 14.2$ & 2.8 \\
\hline \multirow[t]{2}{*}{ Soleidae } & Buglossidium luteum & 1 & - & $<0.1$ & - & 4.2 & - & 0.7 & - \\
\hline & Pegusa lascaris & 3 & - & $<0.1$ & - & 12.5 & - & $1.5 \pm 0.4$ & - \\
\hline TOTAL & & 13556 & 1304 & & & & & & \\
\hline
\end{tabular}

Data for horizontal tows are mean \pm standard deviation or a single value is given for single samples. 
$\frac{\mathfrak{0}}{0}$

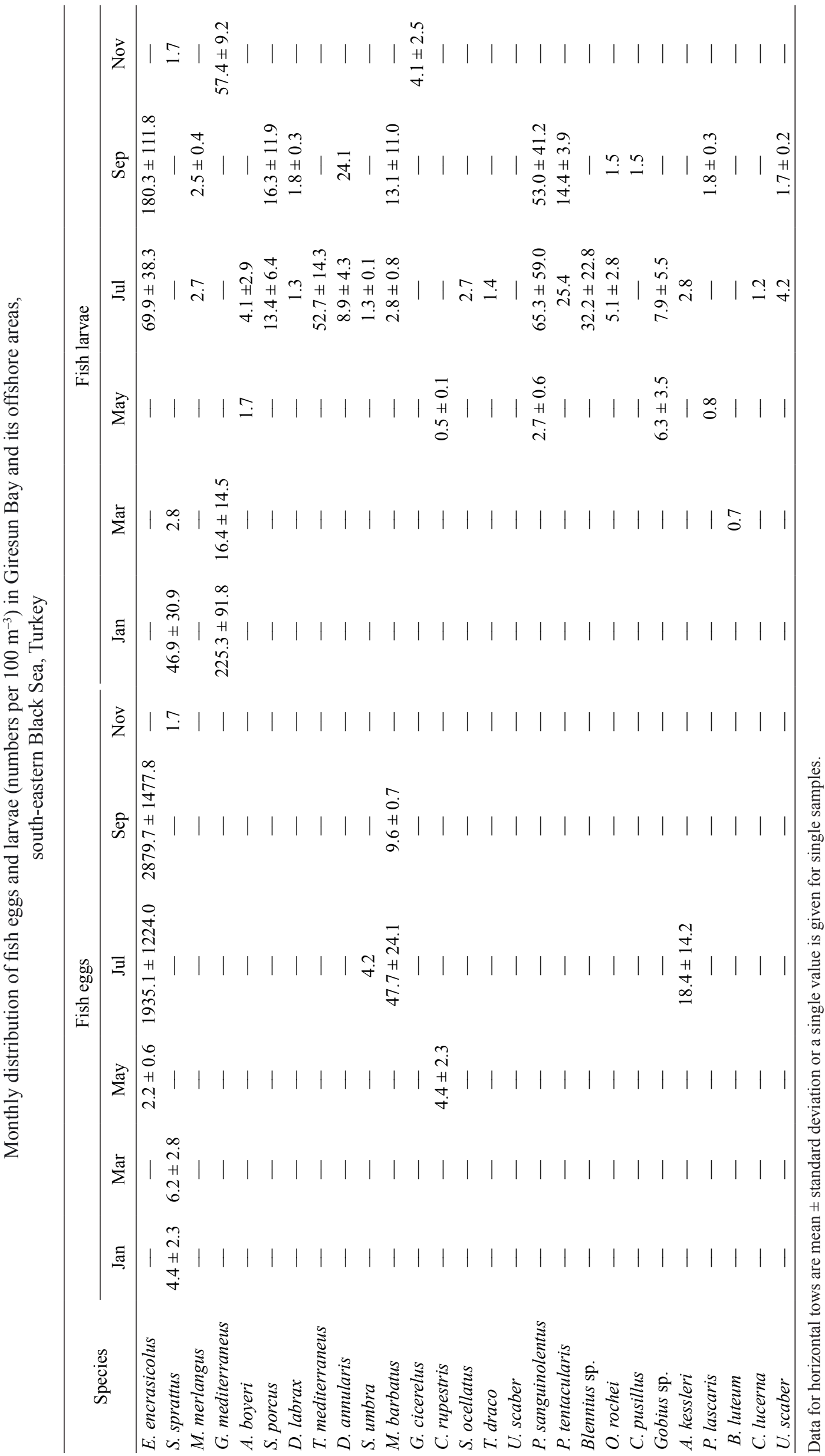




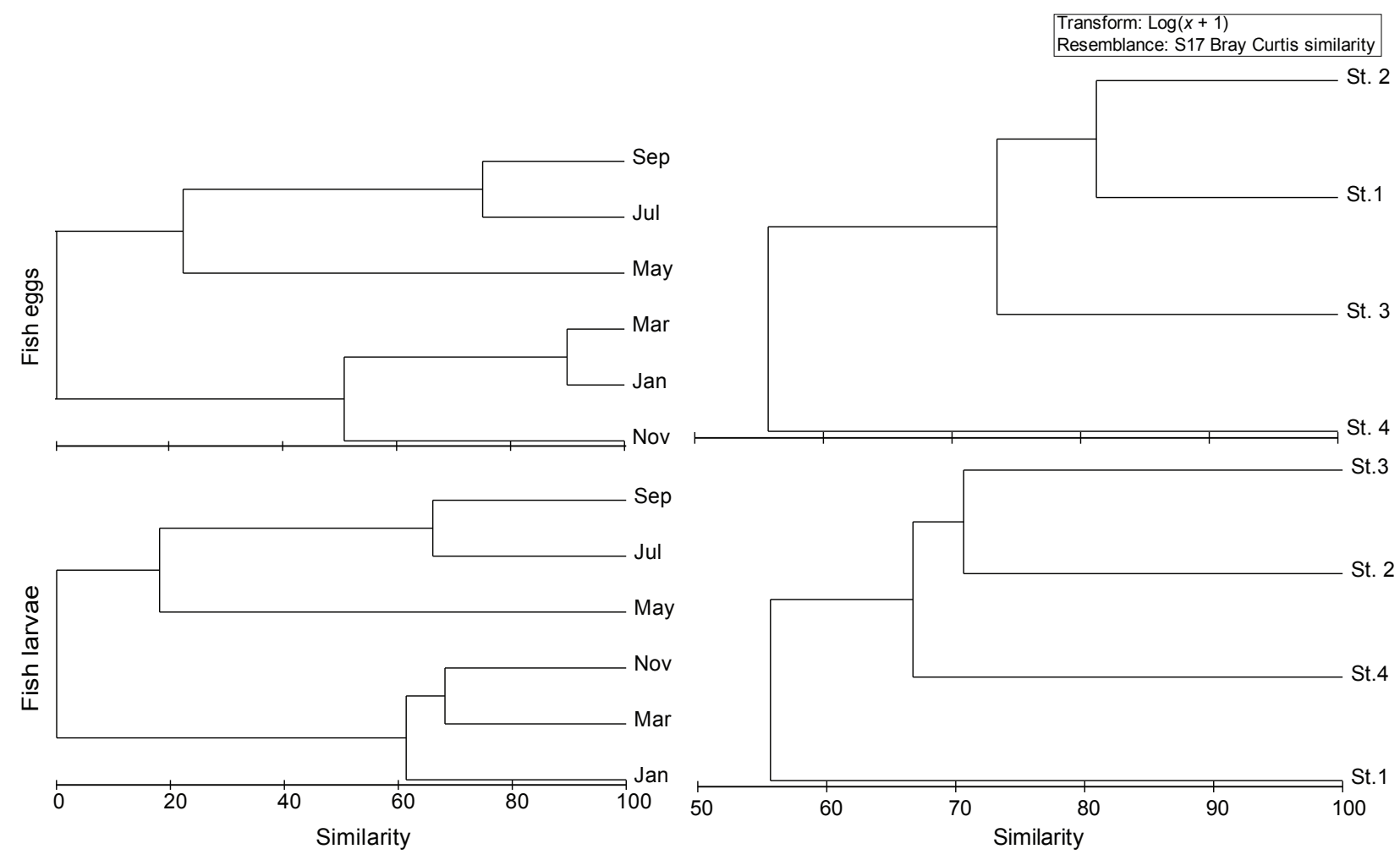

Fig. 4. Dendrogram showing the similarity of ichthyoplankton distribution between different sampling months and stations from Giresun Bay and its offshore areas, the south-eastern Black Sea, Turkey

$16.4^{\circ} \mathrm{C}$ ) which is in accordance with the study by obtained the largest amount of total eggs collected in Şahin and Hacimurtazaoğlu (2013) off the coasts of June and July while only $3 \%$ of the total eggs collected İyidere, and Rize, in the south-eastern Black Sea, were acquired in August and October. In contrast, in the Turkey. The spawning period of E. encrasicolus in the Turkish waters runs from May through September (Gordina et al. 1997, Şahin and Hacimurtazaoğlu 2013, Başar unpublished*, Yüksek unpublished ${ }^{* *}$ ) which was supported by the presently reported study. The abundance of E. encrasicolus eggs increased from May through September as the surface water temperatures increased and hence, the most favourable temperature range was 15.5 to $25.3^{\circ} \mathrm{C}$. This is in line with the findings of Dehnik (1973) and Niermann et al. (1994) who also observed the maximal spawning activity of anchovy at $>20^{\circ} \mathrm{C}$ in the Black Sea. Furthermore, our result is consistent with the findings of Zarrad et al. (2006), who stated a similar range of temperature for anchovy spawning in the Mediterranean Sea. In contrast, the peak spawning activity of E. encrasicolus in the Bay of Biscay was recorded at temperatures ranging from 16 to $18.5^{\circ} \mathrm{C}$ and appeared to decrease at higher temperatures (Motos et al. 1996). Şahin and Hacimurtazaoğlu (2013) reported the highest density of E. encrasicolus eggs in June from offshore stations. This corresponds with the presently reported study where the maximum number of eggs was found at stations St. 1 and St. 2 (offshore sites). presently reported study, the highest amount of total eggs was obtained in September followed by July (Table 2).

In the presently reported study, both eggs and larvae of E. encrasicolus were significantly correlated with the temperature. Kideys et al. (1999) investigated the distribution of eggs and larvae of anchovy in the southern Black Sea during 1992, 1993, and 1996. They found a significant positive correlation between E. encrasicolus eggs and temperature for the 1992 survey, and larvae and temperature for 1996 surveys. However, there was a lack of correlation between eggs and temperature for the 1993 and 1996 surveys, and larvae and temperature for 1992 and 1993 surveys (Kideys et al. 1999). Furthermore, Malavolti et al. (2018) stated a weak positive correlation between eggs and temperature, and larvae and temperature in south-western Adriatic Sea $(P>0.05)$.

The colder months were exclusively covered by Gaidropsarus mediterraneus, Sprattus sprattus, Buglossidium luteum, and Gymnammodytes cicerelus due to the relatively low spawning temperature preferences of these species. Our results agree with the published data of Daban and Yüksek (2017) for G. mediterraneus, Ferreiro and Labarta (1984) for S. sprattus, and Ferreiro However, the Şahin and Hacimurtazaoğlu (2013) study and Labarta (1988) for B. luteum. However, the larvae

\footnotetext{
" Başar E. 1996. Surmene Koyu'ndaki bazı teleostat balıkların pelajik yumurta ve larvalarının mezsimsel dağılımı. [Seasonal distribution of the pelagic eggs and larvae of some teleost fish in Surmene Bay.] MSc thesis, Karadeniz Technical University, Trabzon, Turkey. [In Turkish.]

${ }^{* *}$ Yüksek A. 1993. Marmara denizi’nin kuzey bolgesinde teleostat balıkların pelajik yumurta ve larvalarının dağılımı ve bolluğu (Bakırköy Marmara Ereğlisi). [The distribution and abundance of pelagic eggs and larvae of the teleostat fish in the northern region of the Marmara Sea (Bakırköy Marmara Ereğlisi).] PhD thesis, Istanbul University, İstanbul, Turkey. [In Turkish.]
} 


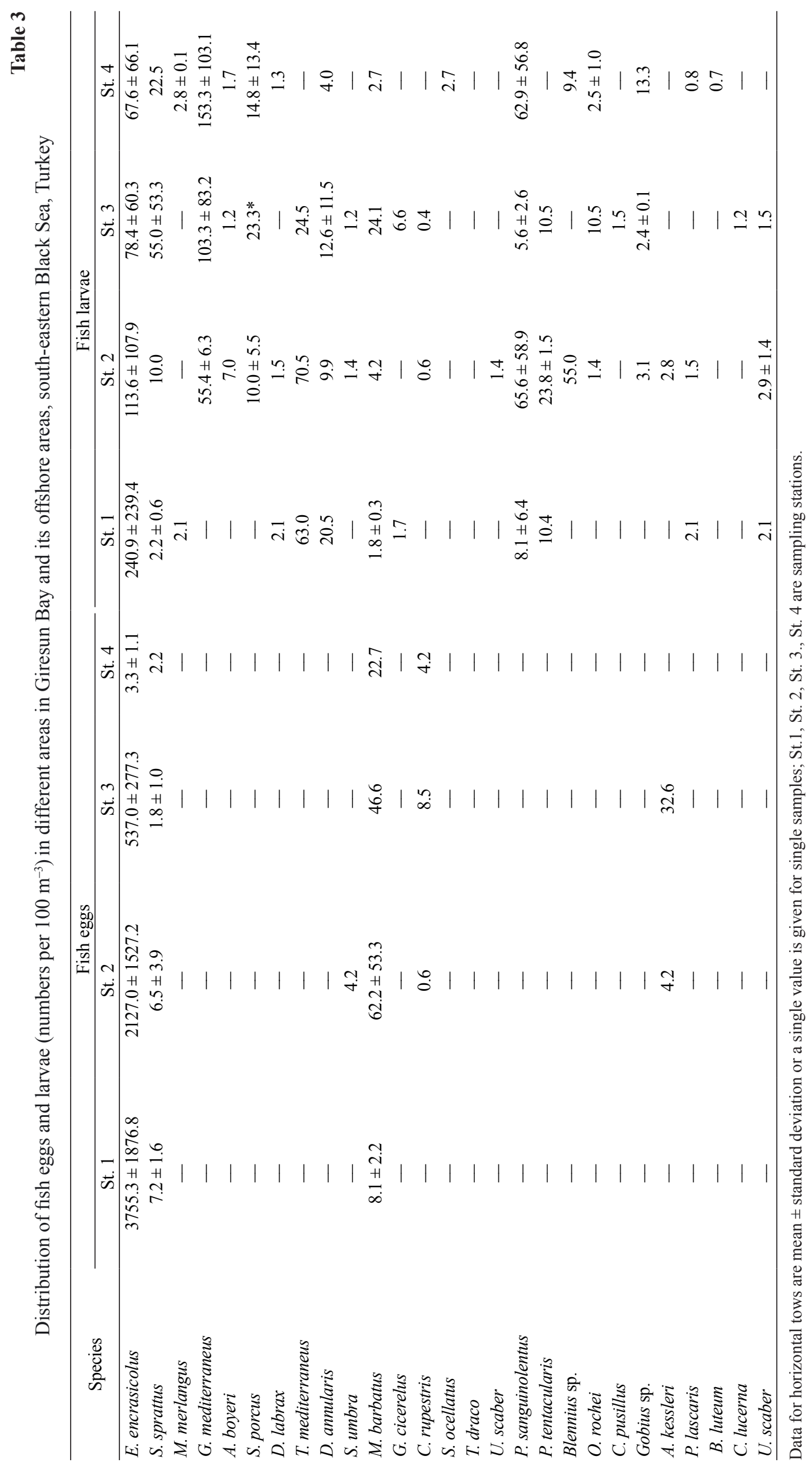


Table 4

Results of SIMPER analysis (based on Bray-Curtis) on the composition of ichthyoplankton from different surveyed stations of Giresun Bay and its offshore areas, south-eastern Black Sea, Turkey

\begin{tabular}{|c|c|c|c|c|c|c|c|}
\hline Stations & $\begin{array}{c}\text { Mean } \\
\text { dissimilarity } \\
{[\%]}\end{array}$ & $\begin{array}{l}\text { Discriminating } \\
\text { species } 1\end{array}$ & $\begin{array}{c}\text { Contribution } \\
{[\%]}\end{array}$ & $\begin{array}{l}\text { Discriminating } \\
\text { species } 2\end{array}$ & $\begin{array}{c}\text { Contribution } \\
{[\%]}\end{array}$ & $\begin{array}{l}\text { Discriminating } \\
\text { species } 3\end{array}$ & $\begin{array}{c}\text { Contribution } \\
{[\%]}\end{array}$ \\
\hline \multicolumn{8}{|c|}{ Fish eggs } \\
\hline $1-2$ & 28.1 & E. encrasicolus & 97.6 & M. barbatus & 2.2 & S. sprattus & 0.1 \\
\hline $1-3$ & 75.0 & E. encrasicolus & 99.2 & A. kessleri & 0.3 & M. barbatus & 0.3 \\
\hline $1-4$ & 99.5 & E. encrasicolus & 99.8 & S. sprattus & 0.1 & M. barbatus & 0.1 \\
\hline $2-3$ & 59.0 & E. encrasicolus & 97.3 & M. barbatus & 1.6 & A. kessleri & 0.6 \\
\hline $2-4$ & 98.9 & E. encrasicolus & 98.0 & M. barbatus & 1.6 & S. sprattus & 0.3 \\
\hline $3-4$ & 95.5 & E. encrasicolus & 96.3 & A. kessleri & 2.0 & M. barbatus & 1.4 \\
\hline \multicolumn{8}{|c|}{ Fish larvae } \\
\hline $1-2$ & 51.1 & E. encrasicolus & 36.0 & P. sanguinolentus & 25.5 & G. mediterraneus & 15.6 \\
\hline $1-3$ & 64.0 & E. encrasicolus & 37.8 & G. mediterraneus & 36.0 & S. sprattus & 12.3 \\
\hline $1-4$ & 77.9 & G. mediterraneus & 39.2 & E. encrasicolus & 29.6 & P. sanguinolentus & 14.7 \\
\hline $2-3$ & 50.6 & G. mediterraneus & 26.1 & P. sanguinolentus & 23.6 & S. sprattus & 13.1 \\
\hline $2-4$ & 41.6 & G. mediterraneus & 50.1 & E. encrasicolus & 13.2 & T. mediterraneus & 10.1 \\
\hline $3-4$ & 35.1 & P. sanguinolentus & 29.9 & G. mediterraneus & 26.1 & S. sprattus & 15.2 \\
\hline
\end{tabular}

SIMPER $=$ Similarity Percentage Analysis.

of G. cicerelus were also caught in the Northern Cyprus marine areas during summer when water temperature was 26.8 to $28.8^{\circ} \mathrm{C}$ (Çoker and Cihangir 2015). Moreover, Hoşsucu and Ak (2002) reported B. luteum in the Gulf of Izmir throughout the year.

The abundance of E. encrasicolus eggs and larvae seemed to increase from inshore to offshore sites highlighting the preference of this species to deeper waters for spawning as well as nursery areas. Zarrad et al. (2012) and Malavolti et al. (2018) also observed that spawning area of E. encrasicolus in the eastern coast of Tunisia and the south-western Adriatic Sea was confined to deeper waters and the fish apparently avoided shallower areas. Contrary to Pattrick and Strydom (2014) and Malavolti et al. (2018), in our study, the larvae (nursery area) of $E$. encrasicolus were also confined to deeper waters and their highest abundance was recorded from stations St. 1 and St. 2. Though, the larvae of some other fish species, such as G. mediterraneus, S. porcus, M. barbatus, and Gobius sp. tended to reside in the near-shore part of Giresun Bay (Table 3). The spawning strategy of E. encrasicolus might thus be avoidance of co-occurring with other species during the planktonic phases (Palomera and Sabatés 1990). Generally, the zooplankton biomass in coastal areas is high (due to higher photosynthetic activity), and hence, provides sufficient and suitable food for fish larvae (Pattrick and Strydom 2014, Malavolti et al. 2018). Several other studies have confirmed that the nursery areas generally exist close to the shore, while the spawning grounds are confined to deeper waters $(>150 \mathrm{~m})$ (Malavolti et al. 2018).

In conclusion, the resulting data identified waters off Giresun as an important spawning site of E. encrasicolus where their density increased from inshore to offshore sites. In the Turkish waters of the Black Sea, the closed fishing season has been imposed from 15 April to 1
Table 5

Pearson correlation coefficient between fish eggs and larvae, and environmental parameters, temperature and salinity in Giresun Bay and its offshore areas, southeastern Black Sea, Turkey

\begin{tabular}{|c|c|c|c|c|}
\hline \multirow{2}{*}{ Species } & \multicolumn{2}{|c|}{ Salinity } & \multicolumn{2}{|c|}{ Temperature } \\
\hline & Egg & Larvae & Egg & Larvae \\
\hline E. encrasicolus & $-0.695^{\mathrm{B}}$ & -0.208 & $0.725^{\mathrm{B}}$ & $0.848^{\mathrm{B}}$ \\
\hline S. sprattus & 0.412 & $0.617^{\mathrm{A}}$ & $-0.714^{\mathrm{B}}$ & $-0.710^{\mathrm{B}}$ \\
\hline M. merlangus & -0.051 & - & $0.586^{\mathrm{A}}$ & - \\
\hline G. mediterraneus & $0.589^{\mathrm{A}}$ & - & $-0.503^{\mathrm{A}}$ & 一 \\
\hline A. boyeri & - & -0.144 & - & 0.434 \\
\hline S. porcus & -0.306 & - & $0.697^{\mathrm{B}}$ & - \\
\hline C. lucerna & - & -0.361 & 一 & 0.394 \\
\hline D. labrax & -0.346 & - & $0.678^{\mathrm{B}}$ & - \\
\hline T. mediterraneus & $-0.679^{\mathrm{B}}$ & - & $0.652^{\mathrm{B}}$ & 一 \\
\hline D. annularis & - & -0.290 & - & $0.823^{\mathrm{B}}$ \\
\hline S. umbra & -0.366 & -0.134 & 0.301 & 0.508 \\
\hline M. barbatus & -0.485 & -0.260 & $0.803^{\mathrm{B}}$ & $0.751^{\mathrm{B}}$ \\
\hline G. cicerelus & - & 0.176 & - & 0.049 \\
\hline C. rupestris & -0.459 & -0.500 & -0.050 & -0.100 \\
\hline S. ocellatus & - & 0.269 & - & 0.428 \\
\hline T. draco & -0.366 & - & 0.301 & - \\
\hline U. scaber & $-0.675^{\mathrm{B}}$ & - & $0.644^{\mathrm{A}}$ & - \\
\hline P. sanguinolentus & - & -0.189 & - & $0.826^{\mathrm{B}}$ \\
\hline P. tentacularis & - & -0.298 & - & $0.659^{\mathrm{A}}$ \\
\hline Blennius sp. & - & 0.269 & - & 0.495 \\
\hline O. rochei & -0.337 & - & $0.642^{\mathrm{A}}$ & - \\
\hline C. pusillus & - & -0.361 & - & 0.394 \\
\hline Gobius sp. & - & -0.422 & - & 0.418 \\
\hline A. kessleri & $-0.501^{\mathrm{A}}$ & 0.145 & 0.495 & 0.304 \\
\hline B. luteum & 0.125 & - & -0.325 & - \\
\hline P. lascaris & -0.410 & - & $0.651^{\mathrm{B}}$ & - \\
\hline
\end{tabular}

${ }^{\mathrm{A}}$ significant at $<0.05,{ }^{\mathrm{B}}$ significant at $<0.01$. 
September. Several researchers have proposed to revise this period and extend it until 1 October since September is also known as the most crucial spawning time*. Based on the results of the presently reported study, the closed fishing season for E. encrasicolus in the Black Sea should be extended until October to provide more time to complete the spawning of the species.

\section{ACKNOWLEDGEMENTS}

This study was funded by the Research Fund of the Karadeniz Technical University, Trabzon, Turkey (grant number: 2006.117.001.1).

\section{REFERENCES}

Ahlstrom E.H., Moser H.G. 1980. Characters useful in identification of pelagic marine fish eggs. California Cooperative Oceanic Fisheries Investigations Reports 21: 121-131.

Alkan N., Alkan A., Akbaş U., Fisher A. 2015. Metal pollution assessment in sediments of the southeastern Black Sea coast of Turkey. Soil and Sediment Contamination: An International Journal 24 (3): 290 305. DOI: $10.1080 / 15320383.2015 .950723$

Anonymous 2016. Fishery Products, 2015. Turkish Statistical Institute. [Accessed on 22 August 2018.] http://www.turkstat.gov.tr/PreHaberBultenleri. do? $i d=21720$

Anonymous 2017a. Fishery Products, 2016. Turkish Statistical Institute. [Accessed on 22 August 2018.] http:// www.turkstat.gov.tr/PreHaberBultenleri.do?id=24657

Anonymous 2017b. T.C. Giresun Valiliği, Çevre ve Şehircilik, İl Müdürlüğü, Giresun İli 2016 Yili Çevre Durum Raporu. [Giresun Provincial Directorate of Environment and Urbanization: Environmental Status Report for 2016.] Giresun Çevre ve Şehircilik İl Müdürlüğü, Giresun, Turkey. [In Turkish.]

Checkley D.M.jr., Asch R.G., Rykaczewski R.R. 2017. Climate, anchovy, and sardine. Annual Review of Marine Science 9: 469-493. DOI: 10.1146/annurevmarine-122414-033819

Çoker T., Cihangir B. 2015. Distribution of ichthyoplankton during the summer period in the Northern Cyprus marine areas. Turkish Journal of Fisheries and Aquatic Sciences 15 (2): 231-242. DOI: 10.4194/1303-2712-v15_2_05

Daban I.B., Yüksek A. 2017. Ichthyoplankton community of the Dardanelles Strait, Turkey. Oceanological and Hydrobiological Studies 46 (3): 253-259. DOI: 10.1515/ohs-2017-0027

Dehnik T.V. [Dekhnik T.V.] 1973. Ihtioplankton Čërnogo morâ. [Ichthyoplankton of the Black Sea.] Naukova Dumka, Kiev, USSR. [In Russian.]

Duzgunes E., Emral H., Kasapoğlu N. 2014. General outlines of the fisheries in the Turkish Black Sea. Pp.147-174. In: Düzgüneş E., Öztürk B., Zengin M. (eds.) Turkish Fisheries in the Black Sea. Turkish Marine Research Foundation, Istanbul, Turkey.
Ferreiro M.J., Labarta U. 1984. Spawning areas and seasons of three clupeid species (Sardina pilchardus, Sprattus sprattus and Engraulis encrasicholus [sic]) in the Ria of Vigo (Galician coasts, NW Spain). Cybium 8 (3): 79-96.

Ferreiro M.J., Labarta U. 1988. Distribution and abundance of teleostean eggs and larvae on the NW coast of Spain. Marine Ecology Progress Series 43: 189-199. DOI: 10.3354/meps043189

Gordina A.D., Nikolskiy V.N., Niermann U., Bingel F., Subbotin A.A. 1997. New data on the morphological differences of anchovy eggs (Engraulis encrasicolus L) in the Black Sea. Fisheries Research 31 (1-2): 139145. DOI: 10.1016/S0165-7836(96)00563-2

Grainger R.J.R., Garcia S.M. 1996. Chronicles of marine fishery landings (1950-1994): Trend analysis and fisheries potential. FAO Fisheries Technical Paper No. 359.

Hamer H.H., Malzahn A.M., Boersma M. 2010. The invasive ctenophore Mnemiopsis leidyi: A threat to fish recruitment in the North Sea? Journal of Plankton Research 33 (1): 137-144. DOI: 10.1093/plankt/ fbq100

Hoșsucu B., Ak Y. 2002. The ichthyoplankton of İzmir Bay: A one-year study of fish eggs and larvae. Turkish Journal of Veterinary and Animal Sciences 26 (5): 1033-1042.

Kideys A.E., Gordina A.D., Bingel F., Niermann U. 1999. The effect of environmental conditions on the distribution of eggs and larvae of anchovy (Engraulis encrasicolus L.) in the Black Sea. ICES Journal of Marine Science 56 (Suppl.): 58-64. DOI: 10.1006/ jmsc. 1999.0605

Lopes C.A., Garcia V., Reynalte-Tataje D.A., ZaniboniFilho E., de Oliveira Nuñer A.P. 2014. Temporal distribution of ichthyoplankton in the Forquilha River, upper Uruguay River-Brazil: Relationship with environmental factors. Acta Scientiarum. Biological Sciences 36 (1): 59-65. DOI: 10.4025/actascibiolsci. v36i1.17993

Malavolti S., De Felice A., Costantini I., Biagotti I., Canduci G., Grilli F., Marini M., Tirelli V., Borme D., Caputo Barucchi V., Leonori I. 2018. Distribution of Engraulis encrasicolus eggs and larvae in relation to coastal oceanographic conditions (a south-western Adriatic Sea case study). Mediterranean Marine Science 19 (1): 180-192. DOI: 10.12681/mms. 14402

Motos L., Uriarte A., Valencia V. 1996. The spawning environment of the Bay of Biscay anchovy (Engraulis encrasicolus L.). Scientia Marina 60 (Suppl. 2): 117 140.

Niermann U., Bingel F., Gorban A., Gordina A.D., Gücü A.C., Kideys A.E., Konsulov A., Radu G., Subbotin A.A., Zaika V.E. 1994. Distribution of anchovy eggs and larvae (Engraulis encrasicolus Cuv.) in the Black Sea in 1991-1992. ICES Journal of Marine Science 51 (4): 395-406. DOI: 10.1006/jmsc.1994.1041 
Palomera I., Sabatés A. 1990. Co-occurrence of Engraulis encrasicolus and Sardinella aurita eggs and larvae in the northwestern Mediterranean. Scientia Marina 54 (1): 61-67.

Pattrick P., Strydom N.A. 2014. Larval fish variability in response to oceanographic features in a nearshore nursery area. Journal of Fish Biology 85 (3): 857-881. DOI: $10.1111 / \mathrm{jfb} .12477$

Popescu I. 2010. Fisheries in the Black Sea. European Parliament, Directorate General For Internal Policies; Policy Department B: Structural and Cohesion Policies; Fisheries. IP/B/PECH/NT/2010-05; PE 438.622

Roussel E., Crec'hriou R., Lenfant P., Mader J., Planes S. 2010. Relative influences of space, time and environment on coastal ichthyoplankton assemblages along a temperate rocky shore. Journal of Plankton Research 32 (10): 1443-1457. DOI: 10.1093/plankt/fbq056

Russell F.S. 1976. The eggs and planktonic stages of British marine fishes. Academic Press, London-New York-San Francisco.

Şahin C., Hacimurtazaoğlu N. 2013. Abundance and distribution of eggs and larvae of anchovy (Engraulis encrasicolus, Linnaeus, 1758) and horse mackerel (Trachurus mediterraneus, Steindachner, 1868) on the coasts of the eastern Black Sea. Turkish Journal of Zoology 37 (6): 773-781. DOI: 10.3906/zoo-1212-31

Satilmis H.H., Gordina A.D., Bat L., Bircan R., Culha M., Akbulut M., Kideys A.E. 2003. Seasonal distribution of fish eggs and larvae off Sinop (the southern Black Sea) in 1999-2000. Acta Oecologica 24 (Suppl. 1): S275-S280. DOI: 10.1016/ S1146-609X(03)00022-5

Slastenenko E. 1956. Karadeniz havzası balıkları. [The fishes of the Black Sea basin.] Et ve Balık Kurumu, Umum Mudurluğu Yayınları, İstanbul, Turkey. [In Turkish.]
Smith P.E., Richardson S.L. 1977. Standard techniques for pelagic fish egg and larvae surveys. FAO Fisheries Technical Paper No. 175.

Tacon A.G.J., Metian M. 2009. Fishing for aquaculture: Non-food use of small pelagic forage fish-A global perspective. Reviews in Fisheries Science 17 (3): 305317. DOI: 10.1080/10641260802677074

Topcuoğlu S., Güven K.C., Balkıs N., Kırbaşoğlu Ç. 2003. Heavy metal monitoring of marine algae from the Turkish Coast of the Black Sea, 1998-2000. Chemosphere 52 (10): 1683-1688. DOI: 10.1016/ S0045-6535(03)00301-1

Vinogradov M.E., Šuškina È.A. [Shushkina E.A.], Musaeva È.I., Sorokin P.Û. 1989. Novyj vseleniec v Černoe more grebnievik Mnemiopsis leidyi (A. Agassiz) (Ctenophora: Lobata). [A newly introduced species in the Black Sea-the ctenophore Mnemiopsis leidyi (A.Agassiz)(Ctenophora: Lobata).] Okeanologiâ 29 (2): 220-224. [In Russian.]

Zarrad R., Alemany F., Jarboui O., Garcia A., Akrout F. 2012. Comparative characterization of the spawning environments of European anchovy, Engraulis encrasicolus, and round sardinella, Sardinella aurita (Actinopterygii: Clupeiformes) in the eastern coast of Tunisia. Acta Ichthyologica et Piscatoria 42 (1): 9-19. DOI: 10.3750/AIP2011.42.1.02

Zarrad R., Missaoui H., Alemany F., Salah R.M., García A., M'Rabet R., Jarboui O., El Abed A. 2006. Spawning areas and larval distributions of anchovy Engraulis encrasicolus in relation to environmental conditions in the Gulf of Tunis (central Mediterranean Sea). Scientia Marina 70 (Suppl. 2): 137-146.

Received: 24 September 2018 Accepted: 21 January 2019 Published electronically: 15 June 2019 